\title{
In Vitro Micro-propagation of Cordyline and Dieffenbachia Plants
}

\author{
Hassan, H. M. S. and S. A. S. Abdallah \\ Department of Plant Production, Fac. Env. Agric. Sci., El-Arish, Suez Canal Univ., Egypt
}

Received: 5/11/2015

\begin{abstract}
This study was carried out in Plant Tissue Culture Laboratory of the Faculty of Environmental Agricultural Sciences, El-Arish, North Sinai, Suez Canal University, Egypt during the period from April 2013 to March 2015. The objective of this study was to optimize the micro-propagation protocol for Cordyline terminals and Diffenbachia picta cv. "Tropica" in order to make the in vitro propagation feasible and economical by enhancing the slow rate of multiplication of traditional methods. Results indicated that BA at $1.0 \mathrm{mg} / \mathrm{l}^{-1}$ combined with $0.1 \mathrm{mg} / \mathrm{l}^{-1} \mathrm{NAA}$ surpassed all other cytokinins (Kin and 2ip) with significant increase on number of axillary shoots/explant, axillary shoot length, number of leaves/shoot. During establishment stage, Main shoot length $(2.55,3.90 \mathrm{~cm}, 7.33$ and $7.04 \mathrm{~cm}$, respectively) on cordyline and (2.33, $4.19 \mathrm{~cm}, 9.40$ and $6.33 \mathrm{~cm}$, respectively) on dieffenbachia. However, in multiplication stage, data revealed that increasing BA concentrations significantly increased growth of cordyline and dieffenbachia compared with control. Data showed that addition of $2 \mathrm{mg} / \mathrm{l}^{-1}$ BA combined with NAA at $0.1 \mathrm{mg} / \mathrm{l}^{-1}$ recorded the highest values of number of axillary shoots/explant, axillary shoot length, number of leaves/shoot and main shoot length $(2.86,5.55 \mathrm{~cm}$, 9.40 and $8.77 \mathrm{~cm}$, respectively) on cordyline, while values were $2.66,5.66 \mathrm{~cm}, 9.88$ and $8.66 \mathrm{~cm}$, respectively on dieffenbachia. The combination between licorice extract and sucrose significantly increased growth parameters of cordyline. The highest values of number of axillary shoots/explant, axillary shoot length, number of leaves/shoot and main shoot length $(2.30,3.25,6.15$ and 4.20 , respectively) were recorded with on cordyline belongs MS medium +30 $\mathrm{g} / \mathrm{l}^{-1}$ sucrose and licorice at $40 \mathrm{mg} / \mathrm{l}^{-1}$, combined with (BA) at $2 \mathrm{mg} / \mathrm{l}^{-1}$ and $0.1 \mathrm{mg} / \mathrm{l}^{-1} \mathrm{NAA}$. On the other side, number of axillary shoots/explant of dieffenbachia was not affected by the medium supplementation with the mentioned factors. For rooting stage, results revealed that NAA was the best auxin in roots induction of cordyline and dieffenbachia with high significant increase in root length and number of roots. While, there was no difference among NAA, IBA and IAA in rooting percentage. Moreover, NAA at $1.0 \mathrm{mgl}^{-1}$ recorded the highest values of number of roots and root length (10.00 and $21.33 \mathrm{~cm}$, respectively) on cordalyine and $(8.00$ and $8.53 \mathrm{~cm}$, respectively) on dieffenbachia. Rooted plantlets were ex vitro acclimatized (95\% survival) of cordyline and dieffenbachia when they were cultured in (1:1:1:1, $\mathrm{v} / \mathrm{v} / \mathrm{v} / \mathrm{v}$ ) peat moss, perlite, vermiculite and sand before transferred to soil.
\end{abstract}

Keywords: Cordyline terminals, Diffenbachia picta cv. "Tropica", BA, Licorice, Sucrose, and NAA

\section{INTRODUCTION}

Cordyline belongs to the family Laxmanniaceae and is very closely related to dracaena (Liamas, 2003). It is a long slender bush up to $3 \mathrm{~m}$ in height and priced for its rich coloured foliage, including variegated forms (Kattoor, 2010). Cordyline are excellent pot plants in their juvenile state and some of them are also suitable for growing in borders and shrubberies under a mild climate, for shade gardens and greenhouse. Most species are widely used for table decorations when they are young. As foliage plants are produced primarily for interior decoration or plants landscaping, a continued desire for multicolour foliage plants in interior designs has resulted in a dramatic increase in ornamental foliage plant production (Ray et al., 2006).

The genus Dieffenbachiasa member of the family Araceae, one of the most important tropical foliage plants (Trigiano and Gray, 2000), it consists of about 30 species and over 100 cultivars with spotted, striped or speckled with cream, white, yellow, gold, silver, or a combination of these colored leaves, 15 to 40 or $50 \mathrm{~cm}$ in length (Henny, 1977; Henny et al., 2000). Species used in interior landscapes are: Dieffenbachia maculate (syn. D. picta), D. amoena and D. seguine (Daffalla et al., 2013).

By traditional mode of propagation from a single plant, like cuttings and air layering, less number of plants is produced taking more time and encountered sometimes with difficulties such as fungal, bacterial and viral diseases (Chase, 1987). Therefore, the use of tissue cultured plantlets can obviously offer more number of plants within a relatively short period (Khan et al., 2004).

Propagation of cordyline and dieffenbachia by in vitro techniques offers many unique advantages over conventional propagation methods such as disinfection, rapid multiplication of valuable genotypes, expeditious release of improved varieties, production of disease-free plants, non-seasonal production and facilitating their easy international exchange (Govil and Gupta, 1997).

The present study aims to optimize the micro propagation protocol for cordyline and dieffenbachia in order to make the propagation feasible and economical to overcome the slow rate of multiplication of traditional methods.

\section{MATERIALS AND METHODS}

This study was carried out in the Plant Tissue Culture Laboratory, Faculty of Environmental Agricultural Sciences (FEAS), El-Arish, North Sinai, Suez Canal University (SCU) during the period from April 2013 to March 2015.

\section{Establishment stage:}

Plants source and surface sterilization:

Cordyline terminals and Diffenbachia picta cv. "Tropica" materials for conducting the experiments were collected from Floriculture and Medicinal Plants Farm, FEAS, El-Arish, Suez Canal Univ. Young shoots from the cordyline and dieffenbachia plants grown in 
the green house were collected and brought into laboratory. Shoots of both plants were washed under running tap water for 1hafter removing all leaves. Explants were sterilized with $70 \%$ ethanol for 30 seconds then washed with sterile distilled water. Explants were transferred to the laminar air flow hood and treated with $0.1 \%$ mercuric chloride $\left(\mathrm{HgCl}_{2}\right)$ solution for 2 minutes then rinsed with sterile distilled water. Explants that contain one node (1-2 cm long) were cut and cultured on the medium.

\section{Media Preparation:}

The sterilized explants were cultured on MS medium (Murashige and Skoog, 1962) solidified with agar at $8 \mathrm{gl}^{-1}$ and supplemented with glycine $\left(2 \mathrm{mgl}^{-1}\right)$, Myo-inositol $\left(0.1 \mathrm{gl}^{-1}\right)$ and sucrose $\left(30 \mathrm{gl}^{-1}\right)$. Medium was supplemented with different concentrations $(0.0$, $\left.1.0 \mathrm{mgl}^{-1}\right)$ of benzyladenine (BA), kinetin (kin) or $6-(\gamma, \gamma$ dimethylally amino) (2ip) combined with $0.1 \mathrm{mgl}^{-1} \alpha-$ naphthalene acetic acid (NAA). The $\mathrm{pH}$ of medium was adjusted to 5.7-5.8 using $\mathrm{KOH}$ or $\mathrm{HCl}$. The medium was cooked then distributed into $300 \mathrm{ml}$ culture jars. Each jar contained $50 \mathrm{ml}$ of the medium and the jars were immediately autoclaved at $121 \mathrm{C}^{\circ}$ and $1.1 \mathrm{Kg} \mathrm{cm}^{2}$ for 20 $\min$.

\section{Culture conditions:}

Cultures in establishment stage were incubated in growth room at $25 \pm 2^{\circ} \mathrm{C}$ under $16 \mathrm{~h}$ /day photoperiod which provided by cool white fluorescent lamps with light intensity of 2000 Lux.

\section{Multiplication stage:}

This stage aimed to increase the number of shoots. So, after six weeks from establishment stage plants were used as a source of multiplication stage. Explants were cultured on MS medium supplemented with BA at0.0, $0.5,1.0,1.5$ or $2.0 \mathrm{mgl}^{-1}$ combined with $0.1 \mathrm{mgl}^{-1} \mathrm{NAA}$.

\section{Effect of licorice and sucrose concentrations:}

This experiment was conducted to determine the effect of sucrose at 0.0 or $30 \mathrm{gl}^{-1}$ with licorice (Glycyrrhiza glabra L.) extract at $0.0,10,20$ or $40 \mathrm{mgl}^{-}$ ${ }^{1}$ on shoots proliferation. All these treatments were supplemented with BA at $2.0 \mathrm{mgl}^{-1}$ combined with 0.1 $\mathrm{mgl}^{-1}$ NAA. For all the above mentioned experiments, number of axillary shoots/explants, main shoot length (cm), axillary shoots length $(\mathrm{cm})$ and No. of leaves/shoot were recorded after eight weeks from incubation date.

\section{Rooting stage:}

Single shoots from multiplication stage were cultured on MS medium free for one month and similar shoots of Cordyline terminals and Diffenbachia picta cv. "Tropica" (about 2-3 cm length) were cultured on MS medium supplemented with different auxin types (i.e. indole acetic acid (IAA), indole butyric acid (IBA) or naphthalene acetic acid (NAA) at 0.0 and $1.0 \mathrm{mgl}^{-1}$ ) to determine their effect on rooting of both plants.

Effect of NAA concentrations on rooting of Cordyline terminals and Diffenbachia picta cv. Tropica shoots during rooting stage:

This experiment was conducted to determine the effect of NAA concentrations at $0.0,0.5,1.0,1.5$ or
$2 \mathrm{mgl}^{-1}$ on rooting of cordyline and dieffenbachia.

\section{Acclimatization stage:}

Plantlets (about 3-4 cm length) were acclimatized by transferring them into black pots $8 \mathrm{~cm}$ diameter filled with two mixtures of soil the first one $(1: 1: 1: 1, \mathrm{v} / \mathrm{v} / \mathrm{v} / \mathrm{v})$ peat moss, perlite, vermiculite and sand; the second one were $(1: 1: 1, \mathrm{v} / \mathrm{v} / \mathrm{v})$ peat moss, perlite and sand. The cultured pots were covered with transparent polyethylene. After one week holes were made in covered polyethylene. These holes were expanded gradually each week. After four weeks plantlets became suitable for transferring to the outside of green house.

Experimental design and statistical analysis:

Experiments were set up in a complete randomized design (CRD). All collected data were analyzed with analysis of variance (ANOVA) procedure using MSTAT-C Statistical Software Package (Michigan State University, 1983). Differences between means were compared using Duncan's multiple range test (Duncan, 1955).

\section{RESULTS AND DISCUSSION}

Establishment stage:

Effect of type of cytokinines combined with $0.1 \mathrm{mgl}^{-1}$ NAAon Cordyline terminals and Diffenbachia picta cv. "Tropica" shoots proliferation and growth during establishment stage:

Results presented in Table (1.a) show the effect of types of cytokinin combined with $0.1 \mathrm{mgl}^{-1} \mathrm{NAA}$ on Cordyline terminals shoots proliferation and growth during establishment stage. Results revealed that BA at $1.0 \mathrm{mgl}^{-1}$ combined with $0.1 \mathrm{mgl}^{-1} \mathrm{NAA}$ in most cases surpassed all other cytokinins with significant increase on number of axillary shoots/explant, axillary shoot length, number of leaves/shoot and main shoot length $(2.55,3.90 \mathrm{~cm}, 7.33$ and $7.04 \mathrm{~cm}$, respectively).

These results are generally in a harmony with the findings of Vardja and Vardja (2001) who found that $1.0 \mathrm{mg} / \mathrm{L} \mathrm{BA}$ resulted in good proliferation and formation of long shoots.

The same trend was observed on Diffenbachia picta $\mathrm{cv}$. "Tropica" when MS media supplemented with BA at $1.0 \mathrm{mgl}^{-1}$ combined with $0.1 \mathrm{mgl}^{-1} \mathrm{NAA}$ and recorded the highest growth parameters [i.e. number of axillary shoots/explant, axillary shoot length, number of leaves/shoot and main shoot length $(2.33,4.19 \mathrm{~cm}, 9.40$ and $6.33 \mathrm{~cm}$, respectively)] as shown in Table (1.b).

These results are different than those findings of Jun et al. (2001) since they used BA alone (3-5 mg/L) for multiple shoot induction and proliferation of 9 species of Dieffenbachia. Iqbal et al. (1999) used 1.0 $\mathrm{mg} / \mathrm{L}$ each of BA and NAA for Dieffenbachia buds (apical and axillary buds) proliferation on MS medium. Whereas, Chao and Li-si. However, Schroeder (2008) showed that $1.5 \mathrm{mg} / \mathrm{L} \mathrm{BA}+0.05 \mathrm{mg} / \mathrm{L} \mathrm{NAA}$ was the suitable medium for axillary bud development. However, Schroeder (2000) added $1.0 \mathrm{mg} / \mathrm{L}$ NAA to 3.0 $\mathrm{mg} / \mathrm{L} 2 \mathrm{iP}$ and $10 \mathrm{mg} / \mathrm{L}$ kin instead of BAP to obtain plantlets from axillary buds of $D$. amoena $\mathrm{cv}$. "Tropica". 
Table (1.a): Effect of cytokinin types combined with $0.1 \mathrm{mgl}^{-1}$ NAA on Cordyline terminals shoots proliferation and growth during establishment stage

\begin{tabular}{lccccc}
\hline Plant & $\begin{array}{c}\text { Cytokinin types } \\
\left.\mathbf{( m g l}^{-1}\right)\end{array}$ & $\begin{array}{c}\text { No. of axillary } \\
\text { shoots/explant }\end{array}$ & $\begin{array}{c}\text { Axillary shoot } \\
\text { length (cm) }\end{array}$ & $\begin{array}{c}\text { No. of } \\
\text { leaves/shoot }\end{array}$ & $\begin{array}{c}\text { Main shoot } \\
\text { length(cm) }\end{array}$ \\
\hline Control & $1.33 \mathrm{~b}$ & $3.50 \mathrm{~b}$ & $5.11 \mathrm{~b}$ & $2.92 \mathrm{c}$ \\
Cordyline & BA & $2.55 \mathrm{a}$ & $3.90 \mathrm{a}$ & $7.33 \mathrm{a}$ & $7.04 \mathrm{a}$ \\
& Kin & $1.55 \mathrm{~b}$ & $3.50 \mathrm{~b}$ & $5.90 \mathrm{~b}$ & $3.82 \mathrm{~b}$ \\
\hline
\end{tabular}

Means having the same letter (s) within the same column are not significantly different according to Duncan s multiple range test at $5 \%$ level of probability.

Table (1.b): Effect of cytokinin types combined with $0.1 \mathrm{mgl}^{-1} \mathrm{NAA}$ on Diffenbachia picta cv. Tropica shoots proliferation and growth during the establishment stage.

\begin{tabular}{lccccc}
\hline Plant & $\begin{array}{c}\text { Cytokinin types } \\
\left(\mathbf{m g l}^{-1}\right)\end{array}$ & $\begin{array}{c}\text { No. of axillary } \\
\text { shoots/explant }\end{array}$ & $\begin{array}{c}\text { Axillary shoot } \\
\text { length }(\mathbf{c m})\end{array}$ & $\begin{array}{c}\text { No. of } \\
\text { leaves/shoot }\end{array}$ & $\begin{array}{c}\text { Main shoot } \\
\text { length(cm) }\end{array}$ \\
\hline \multirow{3}{*}{ Dieffenbachia } & Control & $1.33 \mathrm{~b}$ & $2.60 \mathrm{c}$ & $4.44 \mathrm{c}$ & $3.22 \mathrm{~b}$ \\
& BA & $2.33 \mathrm{a}$ & $4.19 \mathrm{a}$ & $9.40 \mathrm{a}$ & $6.33 \mathrm{a}$ \\
& Kin & $1.33 \mathrm{~b}$ & $3.48 \mathrm{~b}$ & $5.55 \mathrm{~b}$ & $3.86 \mathrm{~b}$ \\
& 2ip & $1.33 \mathrm{~b}$ & $2.75 \mathrm{c}$ & $5.00 \mathrm{~b}$ & $3.50 \mathrm{~b}$ \\
\hline
\end{tabular}

Means having the same letter (s) within the same column are not significantly different according to Duncan's multiple range test at $5 \%$ level of probability.

\section{Multiplication stage:}

Effect of benzyladenine (BA) concentrations combined with $0.1 \mathrm{mgl}^{-1} \mathrm{NAA}$ on Cordyline terminals and Diffenbachia picta cv. Tropica shoots proliferation and growth during multiplication stage:

The main effect of BA concentrations combined with $0.1 \mathrm{mgl}^{-1} \mathrm{NAA}$ on Cordyline terminals shoot proliferation and growth during multiplication stages presented in Table (2.a) and Fig (1). Data revealed that increasing BA concentratins significantly increased growth of Cordyline terminals compared with control. Data show that addition of $2 \mathrm{mgl}^{-1} \mathrm{BA}$ combined with NAA at $0.1 \mathrm{mgl}^{-1}$ recorded the highest values of number of axillary shoots/explant, axillary shoot length, number of leaves/shoot and main shoot length $(2.86,5.55 \mathrm{~cm}$, 9.40 and $8.77 \mathrm{~cm}$, respectively).

These results are generally in a harmony with the findings of Kattoor (2010) on dracaena and cordyline who found that shoot multiplication was significantly promoted on the media containing BAP at $4 \mathrm{mg} / \mathrm{l}$ along with $0.5 \mathrm{mg} / 1$ of NAA. Also, results of Chinnu et al. (2012) on Cordyline sp. indicated that response of explants on Murashige and Skoog's medium and further growth on medium with (BAP) at $4 \mathrm{mg} / \mathrm{l}$, and (NAA) at $0.5 \mathrm{mg} / \mathrm{l}$ and gibberelic acid (GA3) at $5 \mathrm{mg} / \mathrm{l}$, produced the best shoot growth.

Table (2.a): Effect of BA concentrations combined with $0.1 \mathrm{mgl}^{-1} \mathrm{NAA}$ on Cordyline terminals shoots proliferation and growth during multiplication stage

\begin{tabular}{lccccc}
\hline Plant & $\begin{array}{c}\text { BA } \\
\left(\mathbf{m g l} \mathbf{~}^{\mathbf{1}}\right)\end{array}$ & $\begin{array}{c}\text { No. of axillary } \\
\text { shoots/explant }\end{array}$ & $\begin{array}{c}\text { Axillary shoot } \\
\text { length(cm) }\end{array}$ & $\begin{array}{c}\text { No. of } \\
\text { leaves/shoot }\end{array}$ & $\begin{array}{c}\text { Main shoot } \\
\text { length(cm) }\end{array}$ \\
\hline \multirow{3}{*}{ Cordyline } & $\mathbf{0 . 0}$ & $1.33 \mathrm{c}$ & $2.30 \mathrm{~d}$ & $5.33 \mathrm{e}$ & $3.20 \mathrm{e}$ \\
& $\mathbf{0 . 5}$ & $2.22 \mathrm{~b}$ & $2.90 \mathrm{c}$ & $5.90 \mathrm{~d}$ & $4.55 \mathrm{~d}$ \\
& $\mathbf{1 . 0}$ & $2.45 \mathrm{ab}$ & $3.90 \mathrm{~b}$ & $7.33 \mathrm{c}$ & $7.04 \mathrm{c}$ \\
& $\mathbf{1 . 5}$ & $2.60 \mathrm{ab}$ & $4.10 \mathrm{~b}$ & $8.00 \mathrm{~b}$ & $8.20 \mathrm{~b}$ \\
& $\mathbf{2 . 0}$ & $2.86 \mathrm{a}$ & $5.55 \mathrm{a}$ & $9.40 \mathrm{a}$ & $8.77 \mathrm{a}$ \\
\hline
\end{tabular}

Means having the same letter (s) within the same column are not significantly different according to Duncans multiple range test at $5 \%$ level of probability. 


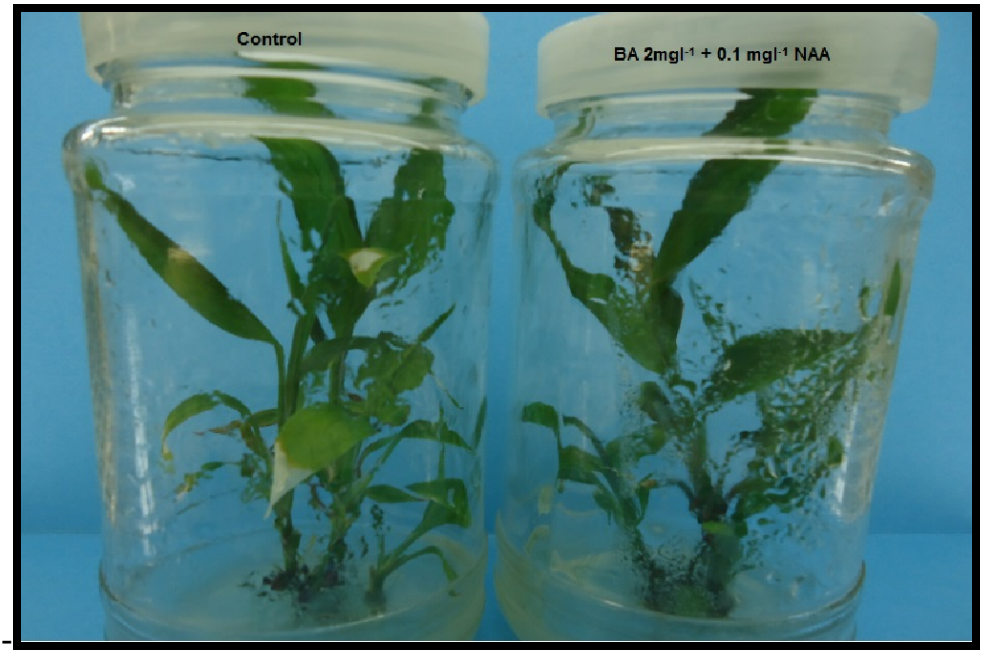

Fig. (1): Effect of BA at $2.0 \mathrm{mgl}^{-1}+0.1 \mathrm{mgl}^{-1} \mathrm{NAA}$ on Cordyline terminals shoots proliferation and growth during multiplication stage.

Data illustrated in Table (2.b) and Fig (2) show that similar trend was observed on Diffenbachia picta cv. "Tropica" when MS supplemented $2 \mathrm{mgl}^{-1}$ BA combined with NAA at $0.1 \mathrm{mgl}^{-1}$ and recorded the highest values of number of axillary shoots/explant, axillary shoot length, number of leaves/shoot and main shoot length $(2.66,5.66 \mathrm{~cm}, 9.88$ and $8.66 \mathrm{~cm}$, respectively).
These results are generally in a harmony with the findings of El-Mahrouk et al. (2006) since they fortified MS media with $8.0 \mathrm{mg} / \mathrm{L} \mathrm{BA}$ and $0.1 \mathrm{mg} / \mathrm{L} \mathrm{NAA} \mathrm{to}$ multiply stem nodes of $D$..Tropic Snow., Elsawy and Bakheet (1999) since who multiplied shoot tip of $D$. picta $\mathrm{cv}$. Tropica on MS medium supplemented with 4.0 $\mathrm{mg} / \mathrm{L}$ BA.

Table (2.b): Effect of BA concentrations combined with $0.1 \mathrm{mgl}^{-1} \mathrm{NAA}$ on "Tropica" shoots proliferation and growth during multiplication stage.

\begin{tabular}{lccccc}
\hline Plant & $\begin{array}{c}\text { BA } \\
\left.\text { (mgl }^{-1}\right)\end{array}$ & $\begin{array}{c}\text { No. of axillary } \\
\text { shoots/explant }\end{array}$ & $\begin{array}{c}\text { Axillary shoot } \\
\text { length(cm) }\end{array}$ & $\begin{array}{c}\text { No. of } \\
\text { leaves/shoot }\end{array}$ & $\begin{array}{c}\text { Main shoot } \\
\text { length(cm) }\end{array}$ \\
\hline & $\mathbf{0 . 0}$ & $1.33 \mathrm{c}$ & $2.60 \mathrm{~d}$ & $5.00 \mathrm{~d}$ & $3.50 \mathrm{e}$ \\
Dieffenbachia & $\mathbf{0 . 5}$ & $1.88 \mathrm{~b}$ & $3.70 \mathrm{c}$ & $7.50 \mathrm{c}$ & $5.50 \mathrm{~d}$ \\
& $\mathbf{1 . 0}$ & $2.33 \mathrm{ab}$ & $4.20 \mathrm{~b}$ & $8.40 \mathrm{~b}$ & $6.33 \mathrm{c}$ \\
& $\mathbf{1 . 5}$ & $2.40 \mathrm{ab}$ & $4.40 \mathrm{~b}$ & $9.33 \mathrm{a}$ & $7.44 \mathrm{~b}$ \\
\hline
\end{tabular}

Means having the same letter (s) within the same column are not significantly different according to Duncan s multiple range test at $5 \%$ level of probability.

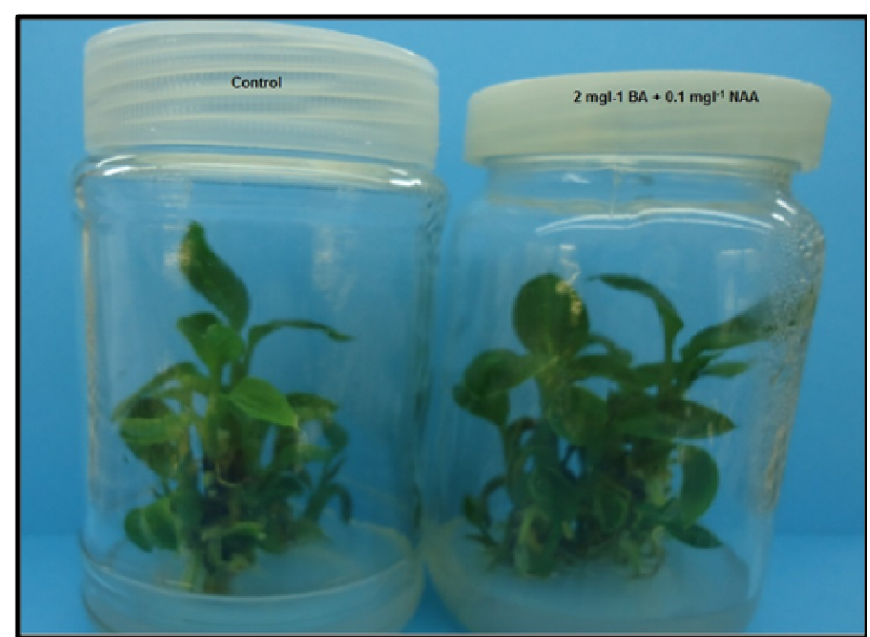

Fig. 2. Effect of BA at $2.0 \mathrm{mgl}^{-1}+0.1 \mathrm{mgl}^{-1} \mathrm{NAA}$ on Diffenbachia picta $\mathrm{cv}$. Tropica shoots proliferation and growth during multiplication stage 
Effect of sucrose and licorice concentrations combined with $2 \mathrm{mgl}^{-1} \mathrm{BA}$ and $0.1 \mathrm{mgl}^{-1} \mathrm{NAA}$ on Cordyline terminals and Diffenbachia picta cv. Tropica shoots proliferation and growth during multiplication stage:

The response of different sucrose and licorice concentrations combined with BA at $2 \mathrm{mgl}^{-1}$ and 0.1 $\mathrm{mgl}^{-1}$ NAA on Cordyline terminals shoots proliferation and growth during multiplication stage are presented in Table (3.a). Results revealed that combination between licorice and sucrose significantly increased growth parameters of Cordyline terminals. The highest values of number of axillary shoots/explant, axillary shoot length, number of leaves/shoot and main shoot length (2.30, 3.25, 6.15 and 4.20, respectively) on Cordyline terminals belongs to $30 \mathrm{gl}^{-1}$ sucrose with licorice at 40 mgl-1 combined with (BA) at $2 \mathrm{mgl}^{-1}$ and $0.1 \mathrm{mgl}^{-1}$ NAA.

The licorice has an impact in shoot proliferation in many plants as reported by Hamza et al. (2011) since they showed that licorices concentrations had a significant effect on all parameter of potato. Licorice at $50 \mathrm{ml} / \mathrm{l}$ with "Diamant" cv. resulted in increasing the average of percentage of growing buds, leaves number, shoot number, nodes number per plant, plant length and root length $(99.77 \%, 11.65,2.88,10.83,12.89$ and 3.69 $\mathrm{cm}$ respectively). Application of licorice extract may be attributed to the fact that licorice roots is rich with many essential minerals, flavonoids, natural antioxidants and carbohydrates including glucose and fructose and more glycosides may be a major factor to increase growth parameters (Morsi et al., 2008).

Table (3.a): Effect of sucrose and licorice concentrations with (BA) at $2 \mathrm{mgl}^{-1}$ and $0.1 \mathrm{mgl}^{-1} \mathrm{NAA}$ on Cordyline terminals shoots proliferation and growth during multiplication stage.

\begin{tabular}{ccccccc}
\hline Plant & $\begin{array}{c}\text { Sucrose } \\
\left.\mathbf{( g l}^{-1}\right)\end{array}$ & $\begin{array}{c}\text { Licorice } \\
\left.\mathbf{( m g l}^{-1}\right)\end{array}$ & $\begin{array}{c}\text { No. of axillary } \\
\text { shoots/explant }\end{array}$ & $\begin{array}{c}\text { Axillary shoot } \\
\text { length }(\mathbf{c m})\end{array}$ & $\begin{array}{c}\text { No. of } \\
\text { leaves/shoot }\end{array}$ & $\begin{array}{c}\text { Main shoot } \\
\text { length }(\mathbf{c m})\end{array}$ \\
\hline & $\mathbf{0}$ & $\mathbf{0}$ & $1.33 \mathrm{e}$ & $2.30 \mathrm{e}$ & $5.33 \mathrm{~b}$ & $3.20 \mathrm{e}$ \\
& $\mathbf{0}$ & $\mathbf{1 0}$ & $1.86 \mathrm{~cd}$ & $2.65 \mathrm{~d}$ & $5.60 \mathrm{ab}$ & $3.55 \mathrm{~d}$ \\
Cordyline & $\mathbf{0}$ & $\mathbf{2 0}$ & $1.95 \mathrm{bc}$ & $2.95 \mathrm{bc}$ & $5.80 \mathrm{ab}$ & $3.70 \mathrm{~cd}$ \\
& $\mathbf{0}$ & $\mathbf{4 0}$ & $2.10 \mathrm{ab}$ & $3.22 \mathrm{a}$ & $5.94 \mathrm{ab}$ & $3.95 \mathrm{a}-\mathrm{c}$ \\
& $\mathbf{3 0}$ & $\mathbf{0}$ & $1.60 \mathrm{~d}$ & $2.80 \mathrm{~cd}$ & $5.80 \mathrm{ab}$ & $3.90 \mathrm{bc}$ \\
& $\mathbf{3 0}$ & $\mathbf{1 0}$ & $1.90 \mathrm{bd}$ & $2.95 \mathrm{bc}$ & $5.96 \mathrm{ab}$ & $3.97 \mathrm{a}-\mathrm{c}$ \\
& $\mathbf{3 0}$ & $\mathbf{2 0}$ & $2.10 \mathrm{ab}$ & $3.11 \mathrm{ab}$ & $6.11 \mathrm{a}$ & $4.12 \mathrm{ab}$ \\
\hline
\end{tabular}

Means having the same letter (s) within the same column are not significantly different according to Duncan's multiple range test at $5 \%$ level of probability.

The response of different sucrose and licorice concentrations combined with BA at $2 \mathrm{mgl}^{-1}$ and 0.1 $\mathrm{mgl}^{-1}$ NAA on Diffenbachia picta cv. "Tropica" shoots proliferation and growth during multiplication stage are presented in Table (3.b). Data showed that addition of licorice and sucrose combined with BA at $2 \mathrm{mgl}^{-1}$ and
$0.1 \mathrm{mgl}^{-1} \mathrm{NAA}$ significantly increased axillary shoot length, number of leaves/shoot and main shoot length. On the other side, number of axillary shoots/explant was not affected by supplementation with the mentioned factors.

Table (3.b): Effect of sucrose and licorice concentrations with (BA) at $2 \mathrm{mgl}^{-1}$ and $0.1 \mathrm{mgl}^{-1}$ NAA on Diffenbachia picta $\mathrm{cv}$. Tropica shoots proliferation and growth during multiplication stage.

\begin{tabular}{lcccccc}
\hline Plant & $\begin{array}{c}\text { Sucrose } \\
\left.\mathbf{( g l}^{-\mathbf{1}}\right)\end{array}$ & $\begin{array}{c}\text { Licorice } \\
\left(\mathbf{m g l}^{-\mathbf{1}}\right)\end{array}$ & $\begin{array}{c}\text { No. of axillary } \\
\text { shoots/explant }\end{array}$ & $\begin{array}{c}\text { Axillary shoot } \\
\text { length }(\mathbf{c m})\end{array}$ & $\begin{array}{c}\text { No. of } \\
\text { leaves/shoot }\end{array}$ & $\begin{array}{c}\text { Main shoot } \\
\text { length }(\mathbf{c m})\end{array}$ \\
\hline & $\mathbf{0}$ & $\mathbf{0}$ & $1.33 \mathrm{a}$ & $2.60 \mathrm{e}$ & $5.00 \mathrm{e}$ & $3.50 \mathrm{f}$ \\
& $\mathbf{0}$ & $\mathbf{1 0}$ & $1.81 \mathrm{a}$ & $2.70 \mathrm{e}$ & $5.48 \mathrm{~d}$ & $3.50 \mathrm{f}$ \\
Dieffenbachia & $\mathbf{0}$ & $\mathbf{2 0}$ & $1.94 \mathrm{a}$ & $3.20 \mathrm{~d}$ & $6.40 \mathrm{c}$ & $4.33 \mathrm{~d}$ \\
& $\mathbf{0}$ & $\mathbf{4 0}$ & $2.0 \mathrm{a}$ & $3.40 \mathrm{~d}$ & $7.33 \mathrm{~b}$ & $4.44 \mathrm{~cd}$ \\
& $\mathbf{3 0}$ & $\mathbf{0}$ & $1.5 \mathrm{a}$ & $3.33 \mathrm{~d}$ & $6.88 \mathrm{~b}$ & $3.90 \mathrm{e}$ \\
& $\mathbf{3 0}$ & $\mathbf{1 0}$ & $2.0 \mathrm{a}$ & $4.30 \mathrm{c}$ & $7.33 \mathrm{~b}$ & $4.70 \mathrm{c}$ \\
& $\mathbf{3 0}$ & $\mathbf{2 0}$ & $2.0 \mathrm{a}$ & $4.90 \mathrm{~b}$ & $7.90 \mathrm{a}$ & $5.22 \mathrm{~b}$ \\
\hline
\end{tabular}

Means having the same letter (s) within the same column are not significantly different according to Duncan's multiple range test at $5 \%$ level of probability. 


\section{Rooting stage:}

Effect of auxin type on rooting of Cordyline terminals and Diffenbachia picta cv. during rooting stage:

Effect of auxin type on rooting of Cordyline terminals is illustrated in Table (4.a) Results Revealed that NAA was the best auxin in cordyline roots induction with high significant increase in root length, gradually significant in number of roots. While, there is no differences between all treatments in rooting percentage. Moreover, NAA at $1.0 \mathrm{mgl}^{-1}$ recorded the highest values of number of roots and root length (10.00 and $21.33 \mathrm{~cm}$, respectively). Kiran et al. (2004) since they reported that in vitro shoots of Mentha piperita were excised from shoot clumps and transferred to rooting medium containing $1 \mathrm{mgl}^{-1} \mathrm{NAA}$.

The same trend was observed on Diffenbachia picta cv. "Tropica" which presented in Table (4.b). Data show that MS supplementation with $1.0 \mathrm{mgl}^{-1}$ NAA gained the highest values of rooting parameters i.e. number of roots and root length $(8.00$ and $8.53 \mathrm{~cm}$, respectively). Similar results for the positive effect of NAA on rooting of dieffenbachia were reported by ElSawy and Bakheet (1999), Chu (2002) and Genfa et al. (1999).

Table (4.a): Effect of auxin type on rooting of Cordyline terminals shoots during rooting stage.

\begin{tabular}{|c|c|c|c|c|}
\hline Plant & $\underset{\left(1.0 \mathrm{mgl}^{-1}\right)}{\text { Auxin }}$ & Rooting percentage & No. of roots & $\begin{array}{l}\text { Root length } \\
\text { (cm) }\end{array}$ \\
\hline \multirow{4}{*}{ Cordyline } & Control & $100 \mathrm{a}$ & $8.00 \mathrm{~b}$ & $10.66 \mathrm{c}$ \\
\hline & IBA $1.0 \mathrm{mgl}^{-1}$ & $100 \mathrm{a}$ & $9.00 \mathrm{ab}$ & $15.33 \mathrm{~b}$ \\
\hline & IAA $1.0 \mathrm{mgl}^{-1}$ & $100 \mathrm{a}$ & $7.33 \mathrm{~b}$ & $8.00 \mathrm{c}$ \\
\hline & NAA $1.0 \mathrm{mgl}^{-1}$ & $100 \mathrm{a}$ & $10.00 \mathrm{a}$ & $21.33 \mathrm{a}$ \\
\hline
\end{tabular}

Means having the same letter (s) within the same column are not significantly different according to Duncan's multiple range test at $5 \%$ level of probability.

Table (4.b): Effect of auxin type on rooting of Diffenbachia picta cv. during rooting stage.

\begin{tabular}{|c|c|c|c|c|}
\hline Plant & $\underset{\left(1.0 \mathrm{mgl}^{-1}\right)}{\text { Auxin }}$ & Rooting percentage & No. of roots & $\begin{array}{l}\text { Root length } \\
\text { (cm) }\end{array}$ \\
\hline \multirow{4}{*}{ Dieffenbachia } & Control & $100 \mathrm{a}$ & $2.33 \mathrm{~b}$ & $2.70 \mathrm{~b}$ \\
\hline & IBA & $100 \mathrm{a}$ & $4.00 \mathrm{~b}$ & $8.43 \mathrm{a}$ \\
\hline & IAA & $100 \mathrm{a}$ & $3.33 \mathrm{~b}$ & $1.66 \mathrm{~b}$ \\
\hline & NAA & $100 \mathrm{a}$ & $8.00 \mathrm{a}$ & $8.53 \mathrm{a}$ \\
\hline
\end{tabular}

Means having the same letter (s) within the same column are not significantly different according to Duncan's multiple range test at $5 \%$ level of probability.

Effect of NAA concentrations on rooting of Cordyline terminals and Diffenbachia picta cv. during rooting stage:

The response of NAA concentrations on rooting of Cordyline terminals shoots during rooting stage are presented in Table (5.a). Results revealed that, there were no significant differences between additions of 1.0 and $1.5 \mathrm{mgl}^{-1} \mathrm{NAA}$.

These results are generally in agreement with the findings of Ooi et al. (1996) who found that, rooting of Dracaena fragrans cv. Massangeana was $100 \%$ for shoots derived from media with $0-2.0 \mathrm{mg} / \mathrm{l} \mathrm{BAP}$ and a relatively low concentration of NAA $\left(0.1 \mathrm{mgl}^{-1}\right)$.

Results presented in Table (5.b) show the effect of NAA concentrations on rooting of Diffenbachia picta cv. "Tropica" shoots during rooting stage. Results clear that rooting percentage was not affected by supplementation with NAA. While, number of roots and root length were significantly affected by NAA additions at $1.0 \mathrm{mgl}^{-1}$.
These results are generally in a harmony with the findings of Dabski and Parzymies (2007) who achieved that the highest number of rooted micro-shoots and the longest roots of Hebe buchananii were formed in the presence of IBA. On the medium supplemented with IAA at 2.5 and $5.0 \mathrm{mgl}^{-1}$, IBA at $5 \mathrm{mgl}^{-1}$ and NAA in concentration of $1 \mathrm{mg} \cdot \mathrm{dm}-3100 \%$ of rooted shoots of Hebe canterburiensis 'Prostrate' were obtained.

\section{Acclimatization stage:}

Effect of soil mixtures on Cordyline terminals and Diffenbachia picta cv. Tropica plantlets during acclimatization:

Rooted plantlets were ex vitro acclimatized (95\% survival) of Cordyline terminals and Diffenbachia picta cv. "Tropica" when they were cultured in peat moss, perlite, vermiculite and sand $(1: 1: 1: 1, \mathrm{v} / \mathrm{v} / \mathrm{v} / \mathrm{v})$ before transferred to soil and successfully grown in the open field. 
Table (5.a): Effect of NAA concentrations on rooting of Cordyline terminals shoots during rooting stage.

\begin{tabular}{lcccc}
\hline Plant & NAA & Rooting percentage & No. of roots & $\begin{array}{c}\text { Root length } \\
\text { (cm) }\end{array}$ \\
\hline \multirow{2}{*}{ Cordyline } & Control & $100 \mathrm{a}$ & $2.33 \mathrm{c}$ & $1.16 \mathrm{~d}$ \\
& NAA 0.5 & $100 \mathrm{a}$ & $4.66 \mathrm{~b}$ & $1.93 \mathrm{c}$ \\
& NAA 1.0 & $100 \mathrm{a}$ & $10.66 \mathrm{a}$ & $15.33 \mathrm{a}$ \\
& NAA 1.5 & $100 \mathrm{a}$ & $10.33 \mathrm{a}$ & $6.00 \mathrm{~b}$ \\
& NAA 2.0 & $100 \mathrm{a}$ & $2.00 \mathrm{c}$ & $1.00 \mathrm{~d}$ \\
\hline
\end{tabular}

Means having the same letter (s) within the same column are not significantly different according to Duncan's ${ }^{\text {'s }}$ mitiple range test at $5 \%$ level of probability

Table (5.b): Effect of NAA concentrations on rooting of Diffenbachia picta cv. during rooting stage.

\begin{tabular}{lcccc}
\hline Plant & NAA & Rooting percentage & No. of roots & $\begin{array}{c}\text { Root length } \\
\text { (cm) }\end{array}$ \\
\hline \multirow{2}{*}{ Dieffenbachia } & Control & $100 \mathrm{a}$ & $3.00 \mathrm{~cd}$ & $3.00 \mathrm{~b}$ \\
& NAA 0.5 & $100 \mathrm{a}$ & $5.33 \mathrm{ab}$ & $1.66 \mathrm{c}$ \\
& NAA 1.5 & $100 \mathrm{a}$ & $6.66 \mathrm{a}$ & $8.16 \mathrm{a}$ \\
& NAA 2.0 & $100 \mathrm{a}$ & $2.00 \mathrm{~d}$ & $1.33 \mathrm{c}$ \\
\hline
\end{tabular}

Means having the same letter (s) within the same column are not significantly different according to Duncan's multiple range test at $5 \%$ level of probability

\section{REFRANCES}

Chao, Z. and C. Li-si (2008). Study on tissue culture and rapid propagation of Dieffenbachia amoena "Kiki". Guangdong Agricultural Sciences, 6: 5052.

Chase, A. R. (1987). Compendium of ornamental foliage plant diseases. The American Phytopathological Society. Press. Minnesota, USA.

Chinnu, J. K., A. N. Mokashi, R. V. Hegde, V. S. Patil and R. V. Koti (2012). In vitro shoot multiplication and ex vitro rooting of cordyline (Cordyline sp.). Karnataka J. Agric. Sci., 25(2): 221-223.

Chu, C. Y. (2002). Micro-propagation and mutation of Dieffenbachia maculate' Rudolph Roehrs-86-A'. MSc. Thesis, National Chung Hsing University Department of Horticulture, Taichung, Taiwan.

Dabski, M. and M. Parzymies (2007). The effect of auxins: IAA, IBA and NAA on rooting of Hebe buchananii (Hook) and Hebe canterburiensis (J. B. Amstar.) 'Prostrate' In Vitro. Acta Sci. Pol., Hortorum Cultus, 6(1): 9-14.

Daffalla, H. M., A. M. Elsheikh and M. M. Khalfala (2013). In vitro micro-propagation of the ornamental plant Dieffenbachia. A Review. Universal Journal of Plant Science, 1(3): 91-99.

Duncan, B. D. (1955). Multiple range and multiple F test. Biometrics, 11: 1-42.

El-Mahrouk, M. E., M. A. Eltarawy, F. A. Menesy and A. I. Metwally (2006). Micro-propagation of dieffenbachia plants from a single stem-nodes. International Journal of Botany, 2(3): 324-328.
El-Sawy, A. and S. A. Bakheet (1999). Propagation of dieffenbachia through tissue culture. Egyptian Journal of Botany, 39(1): 97-107.

Genfa, Z.; Y. Zhang; P. Zhou-Chun; M. Zhang-Zhi; G. F. Zhu; Y. N. Zhang; C. P. Zhou and Z. M. Zang (1999). Tissue culture and rapid propagation of Dieffenbachia. Journal of Tropical and Subtropical Botany, 7(3): 243-247.

Govil, S. and S. Gupta (1997). Commercialization of plant tissue culture in India. Plant Cell, Tissue and Organ Culture, 51: 65-73.

Hamza, M. M., S. A. Abdalmageed, O. H. Abaid (2011). Effect of various concentrations of licorice (Glycyrrhiza glabra) a substitute for sucrose on the In vitro micro-propagation of two potato cvs. (Diamant and Famosa). Iraq Academic Scientific Journal, 37(5): 29-36.

Henny, R., J. L. Goode and W. Ellis (2000). Micropropagation of dieffenbachia In: Trigiano $\mathrm{RN}$, Gray DJ (eds.). Plant Tissue Culture Concepts and Laboratory Exercises, $2^{\text {nd }}$ ed. Boca Roton, pp. 97102.

Henny, R. J. (1977). Breeding, growing and observing dieffenbachia species and seedlings. Proceedings of the Florida State Horticultural Society, 90: 9496.

Iqbal, R.; Z. Ahmad, K. Shoaib and M. Akram (1999). Bud proliferation and regeneration in Dumb-cane (Dieffenbachia seguine) leaf callus. Pakistan Journal of Plant Sciences, 5(1): 29-35.

Jun, S. Z. ;Y. C. Yong and W. Y. Qiang (2001). Tissue culture for rapid propagation of Dieffenbachia 
amoena cv. "Green Sea" and Philodendron erubescens cv. "Emerald King". J. of Zhongkai Agro-technical College, 14(1): 32-35.

Kattoor, C. J. (2010). Micro-propagation studies in dracaena and cordyline. M.Sc. College Agr., Uni. Agr. Sci., Dharwad.

Khan, S.; S. Naz and B. Saeed (2004). In vitro production of Cordyline terminalis for commercialization, Pakistan J. Bot., 36(4): 757761.

Kiran, G.; C. P. Kaviraj, R. B. Venugopal, F. T. Z. Jabeen and S. Rao (2004). Rapid regeneration of Mentha piperita L. from shoot tip and nodal explants. Indian J. Biotechnol., 3(4): 594-598.

Liamas, K. A. (2003). Tropical Flowering Plants, Timber press, Cambridge, pp. 246-247.

Michigan State University (1983). MSTAT-C Micro Computer Statistical Program, Version 2. Michigan State University, East Lansing.

Morsi, M. K., B. El-Magoli, N. T. Saleh, E. M. ElHadidy and H. A. Barakat (2008). Study of antioxidants and anticancer activity of licorice Glycyrrhiza glabra extracts. Egyptian J. Nutr. and Feeds, 2(33): 177-203.
Murashige, T. and F. Skoog (1962). A revised medium for rapid growth and bioassays with tobacco tissue. Physiol. Plant, 15: 473-497.

Ooi, H. L., M. A. Aziz and A. A. Rashid (1996). In vitro responses of Dracaena. "Massangeana" to growth regulators. Pertanika J. Trap. Agric. Sci., 19 (2/3): 123-127.

Ray, T., P. Sahaand and S. C. Roy (2006). Commercial production of Cordyline terminalis (L) Kunth. from shoot apex meristem and assessment for genetic stability of soma clones by isozyme markers, Sci. Hort., 108: 289-294.

Schroeder, M. A. (2000). Production of Dieffenbachia amoena cv. "Tropic" plants by In vitro. Horticulture Argentina, 19(47): 47-49.

Trigiano, R. N. and D. J. Gray (2000). Plant Tissue Culture Concept and Laboratory Exercises, $2^{\text {nd }}$ ed. CRC Pross H. C. USA., pp. 17-21.

Vardja, R. and T. Vardja (2001). The effect of cytokinin type and concentration and number of subcultures on the multiplication rate of some decorative plants. Proc. Estonian Acad. Sci. Biol. Ecol., 50(1): 22-32.

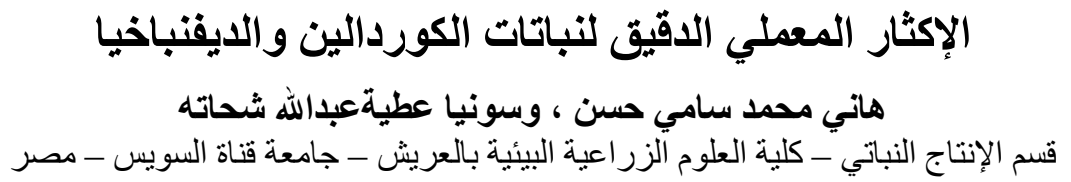

أجريت هذه الدر اسة بمعمل زر اعة الأنسجة النباتية بكلية العلوم الزر اعية البيئية بالعريش، شمال سيناء، جامعة قناة السويس خلال

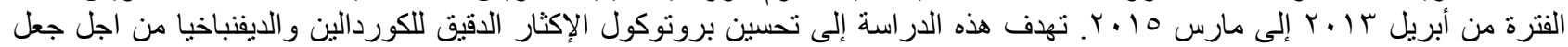

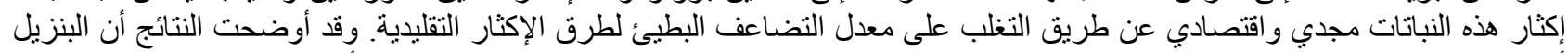

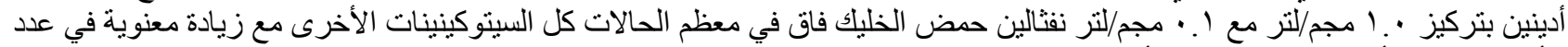

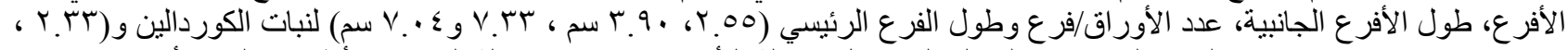

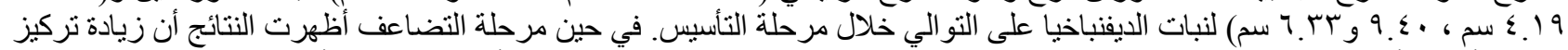

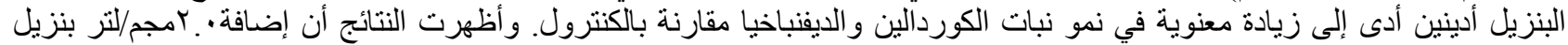

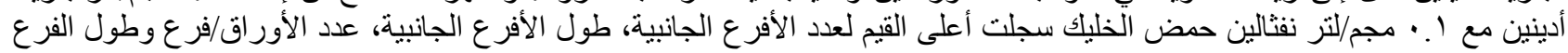

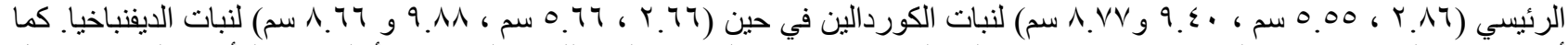

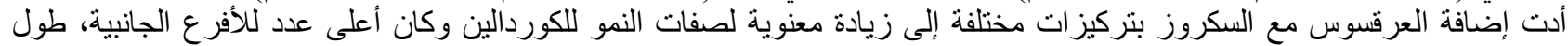

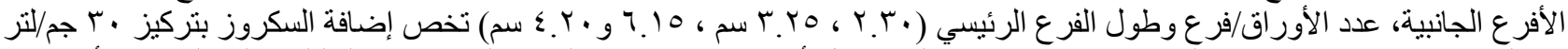

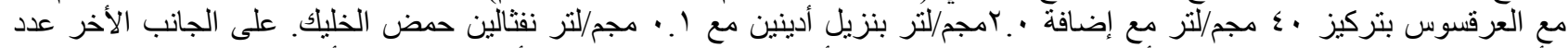

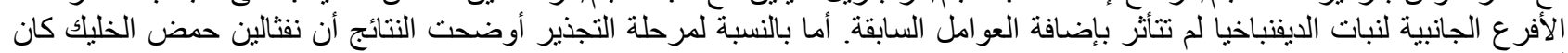

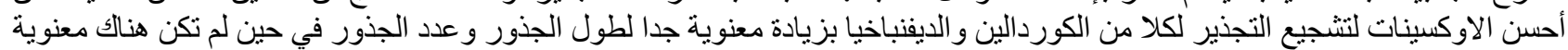

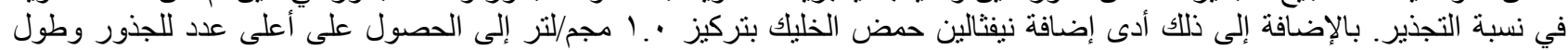

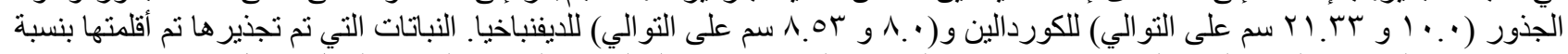

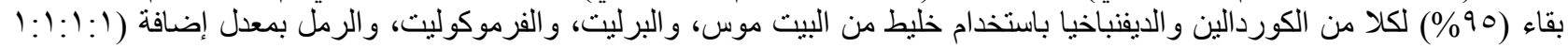

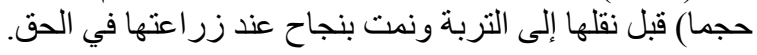

